\title{
PROTOTYPE SMART INSTRUMENT UNTUK KLASIFIKASI PENYAKIT HIPERTENSI BERDASARKAN JNC-7
}

\author{
Dudi Irawan', Izzati Muhimmah' ${ }^{2}$, Tito Yuwono ${ }^{2}$ \\ ${ }^{1}$ Teknik Informatika,Universitas Muhammadiyah Jember \\ Jl. Karimata 49 Jember \\ dudi.irawan77@gmail.com \\ ${ }^{2,3}$ Teknik Informatika,Universitas Islam Indonesia \\ Jl. Kaliurang KM 14.5 Sleman Yogyakarta \\ 2 e.n.dirgahayu@gmail.com \\ 3tito@uii.ac.id
}

\begin{abstract}
High blood disease or famous to known as hypertension almost $95 \%$ the cause is very difficult to know. One way to know the condition of our health is by checking routine to the nearest clinic or hospital. Hypertension is one of the risk factors for dangerous diseases, such as stroke, heart attack, and kidney failure. Hypertension can cause high morbidity (pain) and mortality (death), hypertension is often called silent killer disease. People with Hypertension rarely show early symptoms, and their recognition is usually through screening, or when seeking medical treatment for unrelated health problems. The cause factors of hypertension include weight and height, body fat, and alcohol levels inside of body. To know the condition of body to hypertension need a monitoring system and use tool tensimeter. In this research has been made the means of detecting factor symptoms of hypertension. After the measurements are done by each sensor then the data is processed by Arduino Microcontroller to be processed to computer via serial port (USB). On the computer data that has been sent will be processed using decision tables with databases obtained from experts, the resultin a decision will give classification of hypertension and non-pharmacological management.
\end{abstract}

Keywords: Hypertension, Microcontrol, Arduino, Decision Table

PENDAHULUAN

Penyakit darah tinggi yang lebih dikenal sebagai hipertensi merupakan penyakit yang mendapat perhatian dari semua kalangan masyarakat, mengingat dampak yang ditimbulkannya baik jangka pendek maupun jangka panjang sehingga membutuhkan penanggulangan jangka panjang yang menyeluruh dan terpadu. Penyakit hipertensi menimbulkan angka morbiditas (kesakitan) dan mortalitas (kematian) yang tinggi.

Penyakit hipertensi merupakan penyakit yang timbul akibat adanya interaksi dari berbagai faktor resiko yang dimiliki seseorang. Berbagai penelitian telah menghubungkan antara berbagai faktor resiko terhadap timbulnya hipertensi.

Berdasarkan penelitian yang telah dilakukan tenyata prevalensi (angka kejadian) hipertensi meningkat dengan bertambahnya usia. Dari berbagai penelitian epidemiologis yang dilakukan di Indonesia menunjukan 1,8-28,6\% penduduk yang berusia diatas 20 tahun adalah penderita hipertensi.

Hipertensi, saat ini terdapat adanya kecenderungan bahwa masyarakat perkotaan lebih banyak menderita hipertensi dibandingkan masyarakat pedesaan. Hal ini antara lain dihubungkan dengan adanya gaya hidup masyarakat kota yang berhubungan dengan resiko penyakit hipertensi seperti stress, obesitas (kegemukan), kurangnya olahraga, merokok, alkohol, dan makan makanan yang tinggi kadar lemaknya.

Sudah ada alat untuk mengukur hipertensi yang dinamakan tensimeter. Dengan memiliki alat ini dirumah Pasien hipertensi pemeriksaan tekanan darah secara berkala, sehingga dampak buruk akan hipertensi akan berkurang karena bisa dilakukan pencegahan. Namun tidak semua orang bisa melakukan tensimeter secara baik dan benar, karena dibutuhkan pengetahuan yang cukup supaya dapat menggunakan dan membaca hasil pengukuran dari 
tensimeter. Sedangkan bagi pihak rumah sakit, untuk mengetahui gejala hipertensi proses pemeriksaan melalui banyak tahapan. Sehingga proses tersebut kurang praktis.

\section{LANDASAN TEORI}

\section{A. Tinjauan Pustaka}

Penelitian - penelitian sebelumnya yang dijadikan rujukan utama dalam penelitian ini ada 4, yaitu penelitian oleh RA Tuty Kuswardhani,(2006), Syaiful Hendra dan Sri Kusumadewi (2015), N. Yazid dan A. Harjoko, (2013), dan Damar Triananda Dirta1, Suyanto, ST. (2012). Pada penelitian tersebut membahas tentang konsep yang dipakai dalam penelitian ini yaitu tentang Hipertensi, Mikrontroller, Pengolahan data, sensor, sistem pakar dan penggabungannya.

\section{B. Teori Dasar}

Hipertensi didefinisikan oleh the seventh of the joint national committee on prevention, detection,avaluation and treatment of high blood pressure (JNC 7) sebagai tekanan darah yang lebih tinggi dari 140/90 $\mathrm{mmHg}$ dan diklasifikasikan sesuai derajat keparahannya, mempunyai rentang dari tekanan darah normal tinggi sampai hipertensi maligna (aru W. sudoyo,2006).

Hipertensi adalah tekanan darah sistolik kurang lebih $140 \mathrm{mmhg}$ dan tekanan darah diastolik kurang lebih $90 \mathrm{mmHg}$ atau bila pasien memakai obat antihipertensi (Arief Mansjoer, 2000). Sedangkan menurut Smeltzer C. Suzanne(2005), Hipertensi adalah tekanan darah persisten dimana tekanan sistolik di atas $140 \mathrm{mmHg}$ dan tekanan diastolik di atas $90 \mathrm{mmHg}$. Pada populasi manula, hipertensi didefinisikan sebagai tekanan sistolik $160 \mathrm{mmHg}$ dan tekanan diastolik $90 \mathrm{mmHg}$.

\section{Kalsifikasi Hipertensi}

Menurut The seventh report of the joint national committee on prevention, Detection, evaluation and treatment of high blood pressure(JNC 7) klasifikasi tekanan darah pada orang dewasa terbagi menjadi kelompok normal, pra-hipertensi, hipertensi derajat 1 dan derajat 2.

Tabel 2.1. Klasifikasi hipertensi Menurut JNC 7

\begin{tabular}{|c|c|c|}
\hline $\begin{array}{c}\text { Klasifikasi } \\
\text { Tekanan Darah }\end{array}$ & $\begin{array}{c}\text { TDS } \\
(\mathrm{mmHg})\end{array}$ & TDD $(\mathrm{mmHg})$ \\
\hline Normal & $<120$ & $<80$ \\
Prahipertensi & $120-139$ & $80-89$ \\
Hipertensi & $140-159$ & $90-99$ \\
derajat 1 & Kurang & Kurang lebih \\
& lebih 160 & 100 \\
\hline
\end{tabular}

\begin{tabular}{|l|l|}
\hline $\begin{array}{c}\text { Hipertensi } \\
\text { derajat } 2\end{array}$ & \\
TDS=Tekanan darah sistolik, \\
TDD=Tekanan darah diastolik \\
TD
\end{tabular}

Menurut N. M. Kaplan (2006) memberikan batasan dengan membedakan usia dan jenis kelamin sebagai berikut:

1. Pria, usia $<45$ th, dikatakan hipertensi apabila tekanan darah pada waktu berbaring $>130 / 90$ $\mathrm{mmHg}$.

2. Pria, usia $>45$ th, dikatakan hipertensi apabila tekanan darahnya $>145 / 95 \mathrm{mmHg}$.

3. Pada wanita tekanan darah $>160 / 95 \mathrm{mmHg}$, dinyatakan hipertensi

Berdasarkan penyebabnya hipertensi dibagi menjadi dua golongan yaitu :

1. Hipertensi Esensial atau Hipertensi primer

Hipertensi esensial atau hipertensi primer adalah hipertensi yang etiologinya tidak diketahui dan meliputi lebih kurang 90\% kasus hipertensi. Hipertensi esensial kemungkinan disebabkan bersama-sama menyebabkan meningkatnya tekanan darah (faqih Ruhyyanudin,2006). Hipertensi esensial biasanya muncul pada usia antara 25-55 tahun, sedangkan usia di bawah 20 tahun jarang ditemukan.

\section{Hipertensi Sekunder}

Hipertensi sekunder adalah hipertensi yang penyebabnya dan patofisiologinya diketahui,sehingga dapat dikendalikan dengan obatobatan atau pembedahan (Arjatmo Tjokronegoro,2001). Sekitar 5\% kasus hipertensi telah diketahui penyebabnya dan dapat dikelompokkan seperti dibawah ini:

1). Penyakit parekin ginjal(3\%)

Setiap penyebab gagal ginjal (glomerulonefritis, pielonefritis, sebab-sebab penyumbatan) yang menyebabkan kerusakan parekrim atau cenderung menimbulkan hipertensi dan hipertensi itu sendiri akan mengakibatkan kerusakan ginjal(Houn H.Gray,2005).

2). Penyakit renovaskuler(1\%)

Hipertensi renovaskuler ialah peningkatan tekanan darah sekunder yang disebabkan oleh penurunan perfusi ginjal, baik bilateral, unilateral maupun segmental. Penyebabnya adalah penyakit renovaskuler yang menyebabkan gangguan pasukan darah ginjal 3).Endrokin(1\%)

Pertimbangkan aldosteronisme primer (sindrom cushing) jika terdapat hipokalemia bersama hipertensi.Tingginya kadar aldosteron dan renin yang 
rendah akan mengakibatkan kelebihan (Overload) natrium dan air.

\section{4). Sindrom cushing}

Disebabkan oleh hyperplasia adrenal bilateral yang disebabkan oleh adenoma hipofisis yang menghasilkan ACTH (adrenocortico trophic hormone) pada dua pertiga kasus. Perlu dicurigai jika terdapat hipertensi bersama dengan obesitas, kulit tipis, kelemahan otot dan osteoporosis.

5).Hiperplasia adrenal congenital

Merupakan penyebab hipertensi pada anak(jarang)

\section{6).Feokromositoma}

Disebabkan oleh tumor sel kromatin asal neural yang mensekresikan ketekolamin,90\% berasal dari kelenjar adrenal,kurang lebih $10 \%$ terjadi ditempat lain dalam rantai simpatis, $10 \%$ dari tumor ini ganas dan $10 \%$ adenoma adrenal adalah bilateral.

\section{7). Koarktasio Aorta}

Paling sering mempengaruhi aorta pada atau distal dari arteri subklavia kiri dan menimbulkan hipertensi pada lengan dan menurunkan tekanan kaki,dengan denyut nadi arteri femoralis lemah atau tidak ada.

\section{8). Akibat obat}

Penggunaan obat yang paling banyak berkaitan dengan hipertensi adalah pil kontrasepsi oral (OCP) dengan 5\% perempuan mengalami hipertensi dalam 5 tahun sejak mulai penggunaan.

\section{Penatalaksanaan}

Tujuan deteksi dan penatalaksanaan umum pengobatan hipertensia adalah penurunan risiko mortalitas dan morbiditas yang berhubungan dengan hipertensi. Mortalitas dan morbiditas ini berhubungan dengan kerusakan organ target (misal: kejadian kardiovaskular, gagal jantung, dan penyakit ginjal).

Tujuan terapi adalah mencapai dan mempertahankan tekanan sistolik di bawah 140 $\mathrm{mmHg}$ dan tekanan diastolik $90 \mathrm{mmHg}$ dan mengontrol faktor risiko. Hal ini dapat di capai melalui modifikasi gaya hidup saja, atau dengan obat antihipertensi.

Tabel. 3.1Penatalaksanaan klasifikasi risiko:

\begin{tabular}{|l|c|c|c|c|}
\hline No & $\begin{array}{c}\text { Tekanan } \\
\text { Darah }\end{array}$ & $\begin{array}{c}\text { Kelompok } \\
\text { Risiko A }\end{array}$ & $\begin{array}{c}\text { Kelompok } \\
\text { Risiko B }\end{array}$ & $\begin{array}{c}\text { Kelompok } \\
\text { Risiko C }\end{array}$ \\
\hline 1 & $130-139 / 85-89$ & $\begin{array}{l}\text { Modifikasi } \\
\text { gaya hidup }\end{array}$ & $\begin{array}{l}\text { Modifikasi } \\
\text { gaya hidup }\end{array}$ & Dengan Obat \\
\hline
\end{tabular}

\begin{tabular}{|l|l|l|l|l|}
\hline 2 & $140-159 / 90-99$ & $\begin{array}{l}\text { Modifikasi } \\
\text { gaya hidup }\end{array}$ & $\begin{array}{l}\text { Modifikasi } \\
\text { gaya hidup }\end{array}$ & Dengan Obat \\
\hline 3 & $\begin{array}{l}\geq 160 / \\
\geq 100\end{array}$ & Dengan Obat & Dengan Obat & Dengan Obat \\
\hline
\end{tabular}

Modifikasi gaya hidup (non pharmakologi) sangat efektif dapat menurunkan risiko kardiovaskular dengan biaya sedikit, dan risiko minimal. Tata laksana ini tetap di anjurkan meski harus disertai obat anti hipertensi karena dapat menurunkan jumlah dan dosis obat. Langkah-langkah yang dianjurkan untuk terapi ini adalah:

- Menurunkan berat badan bila terdapat kelebihan (indeks masa tubuh $\geq 27$ )

- Membatasi alkohol.

- Meningkatkan aktivitas fisik aerobik (30-45 menit /hari).

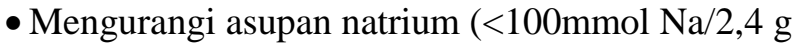
$\mathrm{Na} / 6 \mathrm{~g} \mathrm{NaCl} / \mathrm{hari}$ )

- Mempertahankan asupan kalsium dan magnesium yang ade kuat.

- Berhenti merokok dan mengurangi asupan lemak jenuh dan kolesterol dalam makanan.

Penatalaksanaan dengan obat anti hipertensi bagi sebagian besar pasien dimulai dengan dosis rendah kemudian di tingkatkan seacara titrasi sesuai dengan umur, kebutuhan dan usia. Mengontrol hipertensi terus menerus dan lancar, juga melindungi pasien dari berbagai risiko kematian mendadak, serangan jantung, atau stroke akibat peningkatan tekanan darah mendadak saat bangun tidur.

Pada beberapa pasien mungkin dapat di mulai terapi dengan lebih dari satu obat secara langsung. Pasien dengan tekanan darah $\geq 200 / \geq 120 \mathrm{mmHg}$ harus diberikan terapi dengan segera dan jika terdapat gejala kerusakan organ harus dirawat di rumah sakit.

\section{E. Perancangan Sistem}

Perancangan sistem pada smart instrumen untuk hipertensi ini terdiri dari dua bagian, yaitu bagian hardware dan software.

Pada bagian hardware terdiri dari mikrokontrol dan sensor. Sedangkan pada bagian software yaitu untuk aplikasi interface dan program untuk arduino. 1. Arduino

Arduino merupakan rangkaian elektronik untuk mikro kontrol yang bersifat open source, serta memiliki perangkat keras dan perangkat lunak yang mudah untuk digunakan. Arduino dapat mengenali 


\section{Prototype Smart Instrument Untuk Klasifikasi Penyakit Hipertensi}

lingkungan sekitarnya melalui berbagai jenis sensor dan dapat mengendalikan lampu, motor, dan berbagai jenis aktuator lainnya. Arduino mempunyai banyak jenis, di antaranya Arduino Uno, Arduino Mega 2560, Arduino Fio, dan lainnya.

\section{Sensor Heartrate}

Intensitas gelombang yang dipantulkan tergantung dari tekanan darah pada ujung jari. Jadi, setiap denyut jantung mengubah jumlah gelombang infrared yang terdeteksi oleh sensor photodiode. Dengan pengkondisian sinyal yang tepat, perubahan ini memiliki amplitudo pantulan gelombang yang dapat diubah menjadi denyut yang disebut pulsa. Sensor pulsa dirancang untuk mengukur IBI (Inter Beat Interval). IBI adalah selang waktu pada denyut jantung dalam mili detik dengan waktu sesaat dari jantung berdetak. BPM (Beat per Minute) berasal setiap denyut dari rata-rata setiap 10 kali IBI.

$$
B P M=60000 /(\text { Rata }- \text { rata nilai } I B I)
$$

3. Sensor Tekanan Udara

Untuk dapat mengetahui tekanan udara secara otomatis maka sensor tekanan memiliki peranan penting untuk melakukan pengontrolan. Sensor tekanan adalah sebuah sensor yang dapat mendeteksi tekanan udara, tekanan gas, tekanan air dan dapat di terapkan untuk mendeteksi tekanan bahan bakar.

Sensor Tekanan MPX2050GP menjadi pilihan alternatif yang dapat di kompensasi Lebih dari 0 derajat celsius sampai 85 derajat celsius memiliki Unik Silicon Tegangan Geser Strain Gauge dan mudah digunakan.

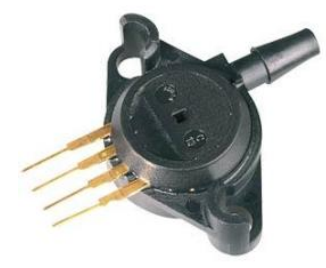

Gambar 2.2 Sensor tekanan

\section{Sensor Berat (Load Cell)}

Load cell adalah komponen utama pada sistem timbangan digital. Tingkat keakurasian timbangan bergantung dari jenis load cell yang dipakai. Sensor load cell apabila diberi beban pada inti besi maka nilai resistansi di strain gauge-nya akan berubah yang dikeluarkan melalui tiga buah kabel. Dua kabel sebagai eksitasi dan satu kabelnya lagi sebagai sinyal keluaran ke kontrolnya. Sebuah load cell terdiri dari konduktor, strain gauge, dan wheatstone bridge.

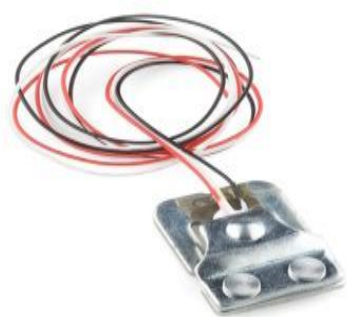

Gambar 2.3 Sensor Berat ( Load Cell)

\section{Sensor Ultrasonik}

Sensor SRF 04 merupakan sensor ultrasonik yang dapat mendeteksi jarak objek dengan cara memancarkan gelombang ultrasonik dengan frekuensi 40 Khz. dan kemudian mendeteksi pantulannya. Sensor ini dapat mengukur jarak antara $3 \mathrm{~cm}$ sampai $300 \mathrm{~cm}$.

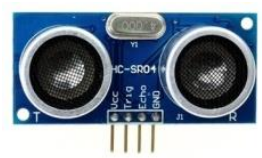

Gambar 2.4 Sensor Jarak

\section{Sensor TGS MQ3}

Sensor alkohol MQ3 memiliki sensitivitas tinggi dan waktu respons yang cepat, Rangkaian driver untuk Sensor alkohol MQ3 ini sangat sederhana, hanya menggunakan 1 buah variable resistor. Output dari Sensor alkohol MQ3 ini berupa tegangan analog yang sebanding dengan kadar alkohol yang diterima.

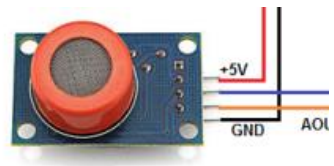

Gambar 2.5 Sensor Alkohol

\section{METODOLOGI}

\section{A. Perancangan Sistem}

Pada perancangan sistem smart instrument untuk penyakit hipertensi akan di desain alat sesuai kebutuhan gejala awal pada penyakit hipertensi. Yang paling menentukan pada penentuan hipertensi adalah TDS $=$ Tekanan darah sistolik, TDD = Tekanan darah diastolik.

Adapun hal-hal yang mempengaruhi terjadinya hipertensi yang lain adalah kandungan alkohol dan indeks massa tubuh. Dengan adanya data - data yang terbaca pada sensor tersebut akan diolah oleh mikro 
kontrol dan di kirimkan ke komputer melalui jaringan nirkabel.

\section{B. Blok Diagram Sistem}

Secara garis besar, blok diagram dalam penyelesaian penelitian ini digambarkan dalam bentuk bagan seperti gambar 3.1. Penjelasan lebih lengkap tentang tahapan-tahapan penelitian akan ditampilkan di bawah ini:

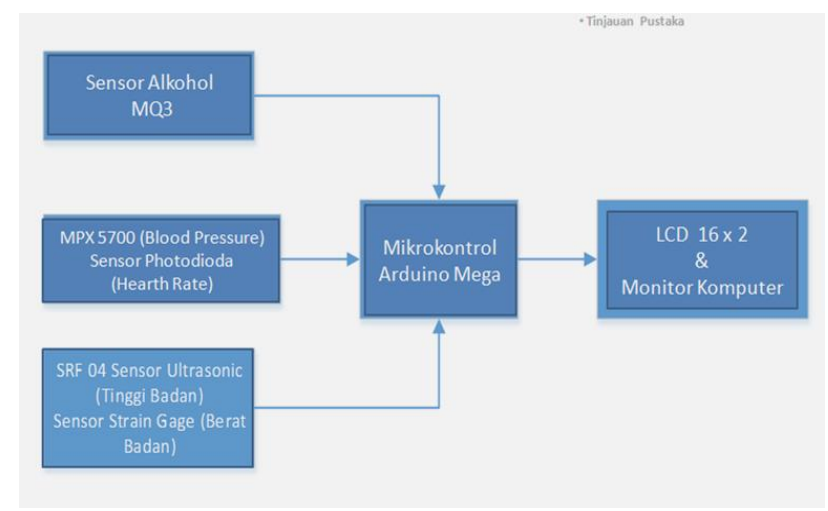

Gambar 3.1 Blok diagram sistem

Sensor akan mengukur besaran analog yang di rubah ke besaran listrik, selanjutnya di masukkan pada mikrokontroler untuk di proses menjadi data digital yang akan di kirim melalui serial port (USB) komputer.

\section{Koneksi Komputer}

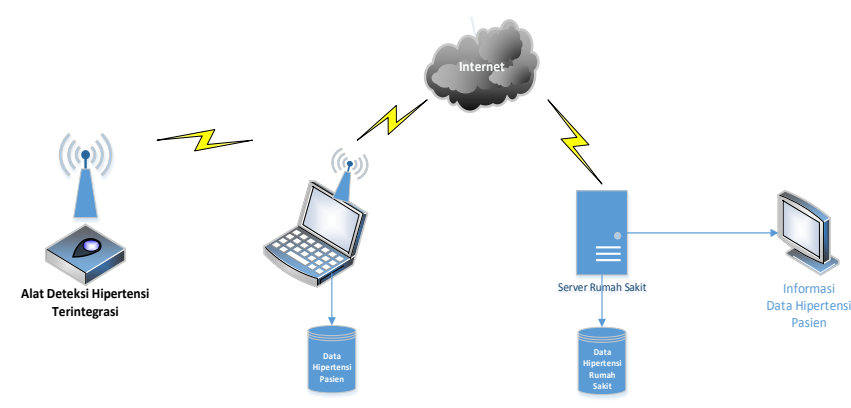

Gambar 3.5 contoh koneksi sistem komputer

Data dari sistem deteksi hipertensi terintegrasi dikirim secara serial melalui port serial. Port serial yang dipakai menggunakan Universal Serial Port (USB). Pada saat alat sudah terkoneksi dengan komputer maka data pasien akan diolah sesuai kebutuhan. Dengan demikian dokter bisa melakukan pemeriksaan dan mengambil tindakan apa bila suatu saat dibutuhkan oleh pasien hipertensi.

\section{Desain Sistem}

Untuk mempermudah hasil pembacaan dan hasil pengolahan data oleh sistem, maka perlu di buat desain interface yang baik. Dengan mengolah data dari sensor diharapkan bisa menghasilkan suatu informasi yg valid bagi pasien hipertensi.

Pada perancangan tampilan interface menggunakan program bantu Borland Delphi versi 7.

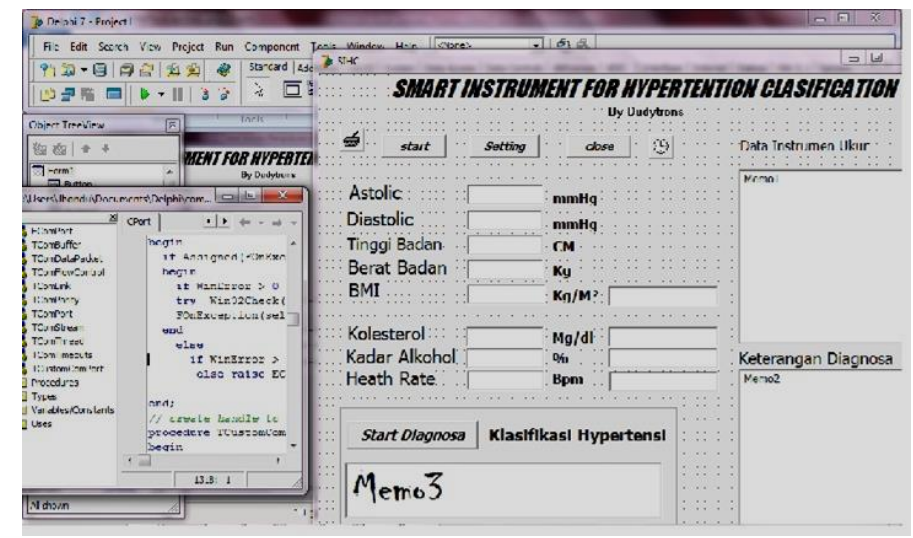

Gambar 3.6 Desain Interface komputer

\section{E. Software Smart Instrument}

Setelah data analog dari semua sensor di rubah menjadi data digital, maka langkah selanjutnya yaitu mengolah data tersebut dengan menggunakan software aplikasi pada komputer. Dengan software tersebut diharapkan suatu hasil output yang sesuai dengan JNC 7 untuk mengklasifikasikan tingkat penyakit hipertensi. Metode pengolahan data tersebut menggunakan tabel tekanan darah JNC-7

Model representasi pengetahuan untuk system klarifikasi penyakit hipertensi berdasarkan JNC-7 ini menggunakan kaidah produksi yang ditulis dalam bentuk Jika - Maka ( If - Then ). Pada Tabel klasifikasi hipertensi ini, jumlah klasifikasi yang akan di jadikan sebagai output, terdari empat output yaitu : Kondisi Normal, Pra-Hipertensi, Hipertensi derajat 1 dan Hipertensi derajat 2.

Tabel 3.1 Klasifikasi Hipertensi
\begin{tabular}{|c|c|c|}
\hline No & Klasifikasi & $\begin{array}{c}\text { Nama } \\
\text { Klasifikasi }\end{array}$ \\
\hline 1 & T 1 & Normal \\
\hline 2 & T 2 & Prahipertensi \\
\hline 3 & T 3 & $\begin{array}{c}\text { Hipertensi } \\
\text { derajat 1 }\end{array}$ \\
\hline
\end{tabular}




\section{Prototype Smart Instrument Untuk Klasifikasi Penyakit Hipertensi}

\begin{tabular}{|l|l|l|}
\hline 4 & T 4 & $\begin{array}{c}\text { Hipertensi } \\
\text { derajat 2 }\end{array}$ \\
\hline
\end{tabular}

\section{HASIL DAN PEMBAHASAN}

\section{A. Proses dan Hasil Penelitian}

Dalam pengambilan data pada tiap masukan data tidak dapat langsung diambil secara bersamaaan. Karena pembacaan nilai besaran tiap masukan berbeda - beda , seperti sensor detak jantung membutuhkan waktu kurang lebih satu setengah menit. Untuk itu semua masukan di setting secara bergantian disesuaikan waktu pengabilan datanya.

Agar mendapatkan nilai yang akurat, sensor perlu di setting sampai mendekati nilai yng baik.

Pada alat ini dibuat berurutan dan setelah data tersimpan maka siap di kirim ke komputer melalui serial interface. LCD $2 \times 16$ berfungsi untuk menampilkan data sementara yang di peroleh dari pembacaan sensor. Jika daftar nilai sudah terisi semua pada display LCD maka siap untuk di kirim ke komputer untuk diolah dan ditampilan pada aplikasi smart Instrument. Pengiriman data digital melalui univesal serial bus (USB). Pengiriman data dilakukan selama 1 detik yang terdiri dari nilai tekanan sistolik, diastolik, tinggi badan, berat badan, kadar alkohol dan detak jantung.

\section{B. Simulasi Interface Komputer}

Pada gambar 4.1 adalah hasil tampilan pengukuran untuk kualifikasi hipertensi tingkat Hipertensi-1. Dengan kondisi tekanan darah sistolik $153 \mathrm{mmHg}$, dengan BMI normal $(24,4)$, Kolesterol dengan kondisi tinggi dan detak jantung yang normal sebesar 72 BPm . Menghasilkan klasifikasi Hipertensi-1 dengan kode K-151.

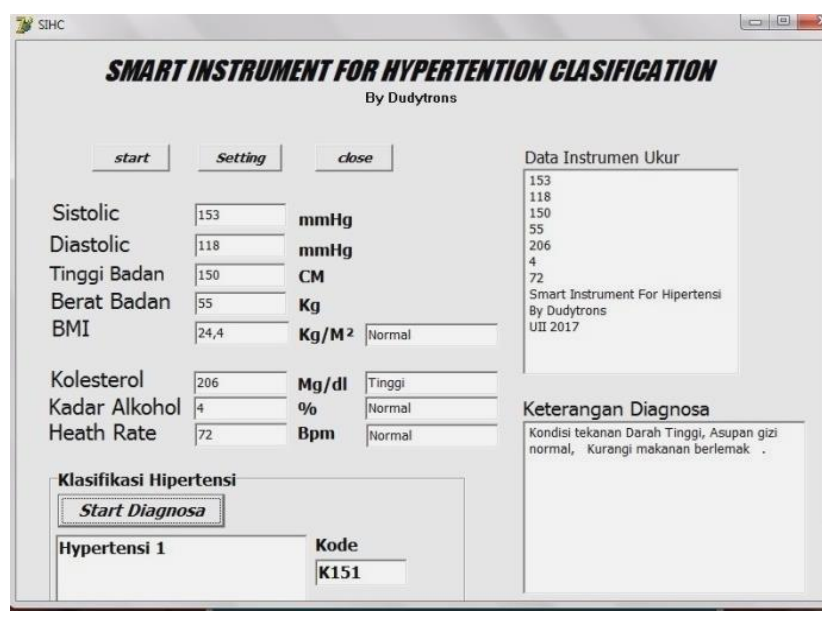

Gambar 4.1 Interface komputer untuk smart instrument

\section{A. Kesimpulan}

Dari hasil pengujian dan pembahasan dapat diambil beberapa kesimpulan sebagai berikut :

- Akurasi alat sangat di tentukan oleh kalibrasi sensor yang baik.

- Komunikasi serial antara mikrokontroler dan komputer harus

- Perancangan alat dan system smart instrument untuk klasifikasi hipertensi berjalan sesuai dengan perencanaan penelitian.

- Implementasi aplikasi system pakar untuk mengklasifikasi penyakit hipertensi berdasarkan JNC-7 memberikan informasi dini yang di butuhkan masyarakat untuk pencegahan penyakit hipertensi lanjut.

B. Saran

Dalam perancangan alat dan system smart instrument ini ada beberapa hal yang perlu di tingkatkan:

- Dalam pengukuran tensimeter perlu di perhatikan posisi dan kondisi pasien sehingga menghasilkan nilai yang akurat.

- Untuk digunakan secara mobile maka alat perlu di beri catu daya portable.

- Untuk penelitian pengembangan, perlu di tambahkan database agar bisa memberi fasilitas penyimpanan data untuk history penyakitnya.

\section{DAFTAR PUSTAKA}

Anita Desiani, Muhammad Arhami (2006). "Konsep Kecerdasan Buatan ", Edisi I, Yogyakarta: Penerbit Andi Offset. Jakarta.

Guyton\&Hall.(1997). Buku Ajar Fisiologi Kedokteran. ECG:

Hendra, Syaiful. Kusumadewi, Sri (2015) "Perancangan Aplikasi Konseling Mahasiswa Menggunakan Metode Case Base Reasoning" Prosiding SNATIF.

JNC 7. "National High Blood Pressure Education Program. The sixth report of the Joint National Committee on Prevention, Detection, Evaluation, and Treatment of High Blood Pressure". ArchIntern Med 1997;157:2413-46. PR

Kaplan NM. (1999), "Hypertension in the elderly". London: Martin Dunitz;.

Kusumadewi, Sri, 2003, "Artifical Intelegence Teknik dan Aplikasinya”, Graha Ilmu, Yogyakarta

Kuswardhani , RA Tuty, (2006), "Penatalaksanaan Hipertensi Pada Lanjut Usia", Bagian Penyakit Dalam FK. Unud, RSUP Sanglah Denpasar 
Jurnal Teknologi Informatika dan Terapan Vol. 04, No 02, Juli - Desember 2017 ISSN: 235-838X

Nursalam. (2003). Konsep Dan Penerapan Metodologi Penenlitian Ilmu Keperawatan. Salemba Medika: Jakarta.

Potter \& Perry. (2001). Fundamental Nursing edisi 4. EGC: Jakarta

Santoso Hari, (2015), “ Panduan Praktis Arduino untuk Pemula" Elang Sakti, Trenggalek.

Turban, Efraim; Aronson, Jay, E.; Liang, Ting-Peng. (2005).

Decision Support Systems and Intelligent Systems. International Edition, Edisi 7. New Jersey: Pearson Prentice-Hall Education International. 
$\underline{\text { Prototype Smart Instrument Untuk Klasifikasi Penyakit Hipertensi }}$ 